\title{
PENDIDIKAN KESEHATAN DALAM UPAYA PRAKTEK HAND HYGIENE PADA PENUNGGU PASIEN DI PUSKESMAS KARANGBINAGUN KABUPATEN LAMONGAN
}

\author{
Suratmi \\ Program Studi S1 Keperawatan STIKES Muhammadiyah Lamongan \\ Email : virgianti_nf@yahoo.com
}

\begin{abstract}
Hand hygiene is a benchmark for preventing the spread of antimicrobial resistance and reducing infection. Indonesian culture that interacts with patients is not only health workers, but also families as patient caregivers. For that hand hygiene should not only be done by health workers but also by families or patients' caregivers in health services. However, compliance in the application of hand hygiene practices when giving health services in some situations are still low. The purpose of this study was to know the effect of health education on hand hygiene practices on patients' care givers in Puskesmas Karangbinangun Lamongan. This research used a pre-experimental method with a one-group pre-post test design. The population were 31 patients' caregivers in Puskesmas Karangbinangun Lamongan who taken by purposive sampling. The instruments of this research are SAP and Observation. Then it was analyzed using the Wilcoxon test. The results showed that the influence of health education on the hand hygiene practices before and after are done hand hygiene health education on inpatients'caregivers obtained a value of $Z=0.5720$ and $P=.000$. It is expected that the patient's caregivers will be able to maintain hand hygiene properly and accordance with the 6 steps that have been taught and practiced together.
\end{abstract}

Keywords: Hand Hygiene Practices, Health Education

\section{PENDAHULUAN}

Penyakit infeksi masih merupakan penyebab utama tingginya angka kesakitan dan kematian di dunia. Salah satu jenis infeksi adalah infeksi nosokomial. Pencegahan dan pengendalian infeksi nosokomial merupakan pelayanan yang wajib diselenggarakan oleh rumah sakit. Saat ini angka infeksi nosokomual dijadikan salag satu tolok ukur mutu pelayanan rumah sakit. Budaya masyarakat Indonesia yang berinteraksi dengan pasien tidak hanya tenaga kesehatan, namun juga keluarga sebagai penunggu pasien. Untuk itu hand hygiene seharusnya tidak hanya dilakukan oleh tenaga kesehatan namun juga oleh keluarga atau penunggu pasien di tempat pelayanan kesehatan. Namun demikian kepatuhan dalam penerapan praktik kebersihan tangan (hand hygiene) pada saat pelayanan kesehatan masih rendah pada beberapa situasi. (Rosmiati, 2018)

Hand hygiene pada penunggu pasien merupakan suatu prosedur tindakan membersihkan tangan dengan menggunakan sabun atau antiseptic dibawah air 
mengalir atau dengan menggunakan handrub yang bertujuan untuk menghilangkan kotoran dari kulit secara mekanis dan mengurangi jumlah mikroorganisme sementara (Darmadi, 2008). Penunggu pasien merupakan seseorang yang memiliki andil besar terhadap terjadinya infeksi karena penunggu pasien berinteraksi secara langsung dengan pasien kurang lebih selama 24 jam. Kurangnya kesadaran penunggu pasien dalam melakukan hand hygine dapat menimbulkan infeksi silang antara penunggu pasien dengan pasien gambaran kondisi ini dalam pencegahan penularan infeksi menjadi sulit,. Hal ini menjadi salah satu penyebab meningkatnya angka kematian dibalai pengobatan sehingga dapat menjadi masalah kesehatan baru baik di negara maju maupun berkembang (Darmadi, 2008).

Pada penelitian di Negara berkembang penunggu pasien yang menganggap remeh pentingnya hand hygiene masih tergolong tinggi dari 55 Rumah sakit dari 14 Negara berkembang 4 wilayah WHO (Eropa, Mediterania Timur, Asia Tenggara, dan Pasifik Barat) menunjukan rata-rata $8,7 \%$ dari penunggu pasien tidak melakukan hand hygiene atau sekitar 1,4 juta penunggu pasien tidak melakukan hand hygiene di Rumah Sakit di Timur Tengah dan Asia Tenggara, masing-masing sebesar 11,8\% dan 10,8\% (Tiet, 2004). Di Indonesia, dalam penelitian 11 Rumah Sakit di Jakarta 9,8\% penunggu pasien tidak melakukan hand hygiene. Menurut Nuniek, (2015) telah dilakukan penelitian di RSUD Kraton Kabupaten Pekalongan, yang memiliki pengetahuan hand hygine menggunakan lotion antiseptic diruang bangsal perawatan kelas III pada 722 orang diambil responden sebanyak 156 responden. Dengan kategori baik sebanyak (12,8\%) responden, cukup $(69,2 \%)$ responden, kurang $(17,9 \%)$ responden. Hasil penelitian pengetahuan penunggu pasien tentang hand hygine lotion antiseptic di ruang bangsal perawatan kelas III RSUD Kraton Pekalongan didapat 156 responden. Berdasarkan hasil penelitian masing-masing sebanyak 20 responden berpengetahuan baik, 108 responden berpengetahuan cukup, dan 28 responden berpengetahuan kurang.

Berdasarkan data yang diperoleh dari survei awal yang dilakukan di UPT Puskesmas Karangbinangun dari 10 orang yang dilakukanpraktik hand hygiene terdapat $4(40 \%)$ responden yang berpengetahuan baik, $2(20 \%)$ responden berpengetahuan cukup, dan $4(40 \%)$ responden berpengetahuan kurang. Berdasarkan uraian data diatas maka masalah dalam penetian ini adalah masih kurangnya kesadaran penunggu pasien dalam melakukan hand hygiene.

Menurut Arfianti, (2010) Faktor -faktor yang mempengaruhi kepatuhan hand hygiene yaitu: 1) Usia, 2) Pengetahuan, 3) Jenis kelamin, 4) Tingkat Pendidikan, 5) Sarana dan Prasarana.

Dinas kesehatan Lamongan selalu menggalakan program penyuluhan pendidikan kesehatan hand hygiene berupa upaya promotif dan preventif. Dalam penyampaian promosi kesehatan khususnya pendidikan kesehatan mengenai pentingnya menjaga kebersihan tangan dan kuku ke sela-sela jari. Puskesmas sudah mengaplikasikan berbagai media promosi kesehatan, melalui media cetak maupun 
elektronika untuk melakukan dengan efektif. Juga memicu mereka untuk melakukan kegiatan hand hygiene sesuai dengan langkah - langkah yang benar. Berdasarkan studi pendahuluan di Puskesmas dapat diketahui bahwa tidak semua penunggu pasien melakukan hand hygiene meskipun sudah disediakan media informasi tentang hand hygiene.

Dampak tidak melakukan hand hygiene diantaranya 1) Infeksi Bakteri Salmonella, 2) Diare, 3) Tertular Flu, 3) Cacingan, 4) Hepatitis, 5) Resiko Radang Pernafasan, (Arfanti, 2010).

Kebersihan tangan mengacu pada proses membersihkan tangan dengan melakukan hand hygine dengan menggunakan cairan antiseptic berbasis alcohol. Dengan pengaturan kesehatan, hand hygine yang benar adalah cara paling sederhana untuk mengurangi lintas transmisi mikroorganisme yang terkait dengan infeksi (Darmadi, 2008). Hand hygiene pada penunggu pasien mempunyai pengaruh besar terhadap keselamatan pasien dalam pencegahan infeksi. Selanjutnya adalah ketersediaan fasilitas, merupakan hal yang paling utama dalam pencegahan atau pengendalian infeksi, dengan adanya fasilitas yang terpenuhi dan lengkap mendorong aktif peningkatan kemampuan keluarga pasien dalam metode universal precautions (kewaspadaan universal) yaitu suatu cara penanganan baru untuk meminimalkan penyebaran bakteri, tanpa mempedulikan status infeksi. Dasar kewaspadaan Universal adalah melalui hand hygiene denganbenar, penggunaanalat pelindung, desinfeksi, dalam upaya mencegah transmisi mikroorganisme melaluicairan tubuh (Sulianti, 2010).

Upaya untuk meningkatkan kesehatan bahwa pentingnya melakukan hand hygiene untuk pencegahan dan pengendalian infeksi mutlak harus dilakukan oleh tenga kesehatan, penunggu pasien dan seluruh orang yang terlibat dalam perawatan pasien, dengan menggunakan panduan kebersihan tangan yang benar dan mengimplemantasikan secara efektif, memberi informasi mengenai penting nya hand hygiene bagi penunggu pasien, juga memfasilitasi sarana dan prasarana hand hygiene dengan sarana poster untuk meningkatkan motifasi untuk melakukan hand hygiene keluarga pasien dan sarana prasarana yang menunjang hand hygine (Joko, 2012).

Berdasarkan uraian di atas,maka penulis tertarik untuk melakukan penelitian tentang hubungan penyuluhan pendidikan kesehatan dengan praktik hand hygiene pada penunggu pasien di UPT Puskesmas Karangbinangun.

\section{METODE PENELITIAN}

Desain penelitian ini adalah pra experimental dengan Pendekatan one grup pre-post test. Penelitian dilakukan pada bulan februari sampai dengan maret 2018, lokasi penelitian dilakukan di Puskesmas Karangbinangun Lamongan. Populasi dalam penelitian ini adalah seluruh Penunggu pasien rawat inap Puskesmas 
Karangbinangun berjumlah 31 penunggu pasien. Sampel pada penelitian ini adalah penunggu pasien rawat inap yang memenuhi kriteria inklusi yaitu sebanyak 31 orang. Dalam penelitian ini menggunakan tehnik purposive sampling. Variabel independen dalam penelitian ini adalah Pendidikan Kesehatan. Variabel dependen dalam penelitian ini adalah Praktik Hand hygiene. Penelitian ini bertujuan untuk mencari Pengaruh Pendidikan Kesehatan Terhadap Praktik Hand Hygiene Pada Penunggu Pasien Di Puskesmas Karangbinangun Lamongan dengan menggunakan uji Wilcoxon SPSS.

\section{HASIL DAN PEMBAHASAN}

Tabel 1 Distribusi Penunggu Pasien Berdasarkan jenis kelamin

\begin{tabular}{llcc}
\hline No & Jenis Kelamin & Frekuensi (Orang) & Prosentase (\%) \\
\hline 1 & Perempuan & 27 & 87,1 \\
2 & Laki-laki & 4 & 12,9 \\
\hline Jumlah & & 31 & 100 \\
\hline
\end{tabular}

Berdasarkan tabel 1 dapat diperoleh hasil bahwa dari 31 Penunggu Pasien, sebagian besar berjenis kelamin perempuan yaitu sebanyak 27 orang $(87,1 \%)$, dan hampir setengahnya atau hampir sebagian berjenis kelamin laki-laki yaitu sebanyak 4 orang $(12,9 \%)$

Tabel 2 Distribusi Penunggu Pasien Berdasarkan usia

\begin{tabular}{llcc}
\hline No & Usia & Jumlah & Prosentase (\%) \\
\hline 1 & $25-35$ tahun & 17 & $54,9 \%$ \\
2 & $36-45$ tahun. & 9 & $29,0 \%$ \\
3 & $46-55$ tahun & 5 & $16,1 \%$ \\
\hline & Total & 31 & 100 \\
\hline
\end{tabular}

Berdasarkan tabel 2 menunjukkan bahwa dari 31 Penunggu Pasien sebagian besar berusia 25-35 tahun 17 orang (54,9\%), sedangkan sebagian kecil Penunggu Pasien berusia 46-55 tahun 5 orang $(16,1 \%)$.

Tabel 3 Distribusi Penunggu Pasien Berdasarkan Pendidikan

\begin{tabular}{llcc}
\hline No & Pendidikan & Frekuensi & Prosentase (\%) \\
\hline 1 & SD & 4 & $12,9 \%$ \\
2 & SMP & 7 & $22,6 \%$ \\
3 & SMA & 20 & $64,5 \%$ \\
\hline & Total & 31 & 100 \\
\hline
\end{tabular}

Berdasarkan tabel 3 dapat diperoleh hasil dari 40 Penunggu Pasien, sebagian besar Penunggu Pasien berpendidikan SMA yaitu 20 atau (64,5\%), dan sebagian kecil Penunggu Pasien berpendidikan SD yaitu 2 atau (12,9\%). 
Tabel 4 Praktik Hand Hygiene Pada Penunggu Pasien Sebelum Dilakukan Pendidikan Kesehatan.

\begin{tabular}{llcc}
\hline No & Praktik Hand Hygiene & Frekuensi & Prosentase (\%) \\
\hline 1 & Dilakukan & 5 & $16,1 \%$ \\
2 & Tidak dilakukan & 26 & $83,9 \%$ \\
\hline & Total & 31 & 100 \\
\hline
\end{tabular}

Pada tabel 4 menunjukkan bahwa sebelum diberi pendidikan kesehatan, hampir seluruhnya Penunggu Pasien tidak melakukan praktik hand hygiene yaitu sebanyak 26 penunggu pasien (83,9\%), dan sebagian kecil Penunggu Pasien melakukan praktik hand hygiene yaitu 5 penunggu pasien $(16,1 \%)$.

Tabel 5 Praktik Hand Hygiene Setelah Dilakukan Pendidikan Kesehatan

\begin{tabular}{llcc}
\hline No & Praktik Hand Hygiene & Frekuensi & Prosentase (\%) \\
\hline 1 & Dilakukan & 27 & $87,1 \%$ \\
2 & Tidak dilakukan & 4 & $21,9 \%$ \\
\hline & Total & 31 & 100 \\
\hline
\end{tabular}

Pada tabel 5 menunjukan bahwa setelah dilakukan pendidikan kesehatan, hampir seluruhnya penunggu pasien melakukan praktik hand hygiene yaitu sebanyak 27 penunggu pasien atau $(87,1 \%)$ dan sebagian kecil tidak dilakukan hand hygiene dengan baik dan benar yaitu sebanyak 4 penunggu pasien atau $(21,9 \%)$.

\begin{tabular}{|c|c|c|c|c|c|}
\hline \multirow{3}{*}{ No } & \multirow{3}{*}{$\begin{array}{c}\text { Pengaruh P } \\
\text { Praktik Hand } \\
\text { Hygiene }\end{array}$} & $\operatorname{an} \mathrm{K}$ & Terl & raktik & Hygien \\
\hline & & \multicolumn{2}{|c|}{ Pre } & \multicolumn{2}{|c|}{ Post } \\
\hline & & Frek & $\%$ & Frek & $\%$ \\
\hline 1 & Dilakukan & 5 & 16,1 & 27 & 87,1 \\
\hline 2 & Tidak dilakukan & 26 & 83,9 & 4 & 21,9 \\
\hline Total & & 31 & 100 & 31 & 100 \\
\hline
\end{tabular}

Dari tabel diatas menunjukkan bahwa sebelum dilakukan pendidikan kesehatan tentang hand hygiene hampir seluruh penunggu pasien yaitu sebanyak 26 penunggu pasien $(83,9 \%)$ tidak melakukan hand hygiene. Dan sebagian kecil penunggu pasien melakukan hand hygiene yaitu sebanyak 5 penunggu pasien atau $(16,1 \%)$. Setelah dilakukan pendidikan kesehatan tentang hand hygiene hampir seluruh penunggu pasien melakukan hand hygiene sebanyak 27 penunggu pasien atau $(87,1 \%)$. Dan sebagian kecil penungggu pasien yang tidak melakukan hand hygiene 4 penunggu pasien atau $(21,9 \%)$.

Setelah pengumpulan data selesai dilakukan dan didapati distiribusi dari masing-masing data, langkah selanjutnya analisa data menggunakan uji Wilcoxon menggunakan program SPSS pc for windows sign rank untuk mengetahui pengaruh 
pendidikan kesehatan terhadap praktik hand hygiene pada penunggu pasien di Puskesmas Karangbinangun Lamongan tahun 2018 menggunakan SPSS 16 didapatkan $\mathrm{Z}-5,718$ dengan tingkat signifikan $\mathrm{P}, 000(\mathrm{P} \prec 0,05) \mathrm{H} 1$ diterima, artinya terdapat pengaruh pendidikan kesehatan terhadap praktik hand hygiene pada penunggu pasien di Puskesmas Karangbinangun Lamongan tahun 2018.

Pada tabel 4 menunjukkan sebelum diberi pendidikan kesehatan, hampir seluruhnya Penunggu Pasien tidak melakukan praktik hand hygiene yaitu sebanyak 26 penunggu pasien $(83,9 \%)$, dan sebagian kecil Penunggu Pasien melakukan praktik hand hygiene yaitu 5 penunggu pasien $(16,1 \%)$.

Dari data diatas menunjukan bahwa sebelum mendapatkan pendidikan kesehatan penunggu pasien tidak melakukan cuci tangan (hand hygiene) saat sebelum atau sesudah kontak dengan pasien.

Kebanyakan dari penunggu pasien tidak tahu pentingnya cuci tangan dan juga tidak tahu cara melakukan Hand hygiene dengan baik dan benar. Sebelum dilakukan pendidikan kesehatan, penunggu pasien hanya melakukan hand hygiene sekedarnya dan kebanyakan dari penunggu pasien melakukan hand hygiene ketika merasa bahwa kondisi tangan kurang nyaman atau kotor, penunggu pasien hanya mencuci tangan tanpa menggunakan sabun bahkan terkadang mengelapkan tangan yang kotor ke pakaian yang mereka kenakan.

Berdasarkan penjelasan diatas dapat dijelaskan bahwa dalam hal ini seorang perawat harus berperan aktif yaitu melakukan melakukan pendidikan kesehatan secara langsung ke penunggu pasien, instansi pemberi layanan kesehatan harus melakukan kampanye pentingnya cuci tangan dengan memasang poster ataupun member leaflet tentang hand hygiene .

Berdasarkan tabel 6 diatas menunjukkan bahwa setelah dilakukan pendidikan kesehatan hand hygiene hampir seluruhnya penunggu pasien hand hygiene dengan benar dan tepat sebanyak 27 penunggu pasien atau $87,1 \%$.

Setelah dilakukan pendidikan kesehatan pada penunggu pasien tentang hand hygiene mengalami peningkatan dalam melakukan hand hygiene dengan baik dan benar. Penunggu pasien memahami pentingnya menjaga kebersihan tangan dan manfaat dari melakukan hand hygien. Hand hygiene tidak hanya memberikan rasa nyaman dan bersih tetapi juga dapat menghindarkan penunggu pasien dan pasien dari infeksi silang penyakit. dan dapat terhindar dari tertularnya penyakit

Dapat dilihat dari tujuan pendidikan kesehatan hand hygiene adalah untuk mengubah perilaku seseorang atau masyarakat dari perilaku tidak sehat menjadi sehat. Selain itu pendidikan kesehatan dapat pula mengubah perilaku sehat kaitannya dengan budaya sikap dan perilaku menjaga adalah bagian dari budaya kebiasaan adat istiadat, tata nilai atau norma kebudayaan. Kebudayaan adalah sikap dan prilaku serta cara berfikir orang yang terjadinya melalui suatu proses pelajaran Susilo, (2011). 
Berdasarkan hasil penelitian diatas menunjukkan pendidikan kesehatan dan praktik hand hygiene sangat berpengaruh dengan prilaku penunggu pasien karena pendidikan kesehatan dapat mengubah tingkat pengetahuan seseorang mereka kini tau manfaat dan pentingnya melakukan hand hygiene sebelum dan setelah beraktivitas. Setelah dilakukan praktik hand hygiene dengan baik dan benar, pengetahuan penunggu pasien meningkat dan tahu bagai mana cara melakukan hand hygiene dengan baik dan benar.

Setelah pengumpulan data selesai dilakukan dan didapati distiribusi dari masing-masing data, langkah selanjutnya analisa data menggunakan uji Wilcoxon menggunakan program SPSS pc for windows sign rank pengaruh pendidikan kesehatan terhadap praktik hand hygiene pada penunggu pasien di Puskesmas Karangbinangun Lamongan tahun 2018 menggunakan SPSS 16 didapatkan Z 5,718 dengan tingkat signifikan $\mathrm{P}, 000(\mathrm{P}<0,05) \mathrm{H} 1$ diterima, artinya terdapat pengaruh pendidikan kesehatan terhadap praktik hand hygiene pada penunggu pasien di Puskesmas Karangbinangun Lamongan tahun 2018.

Praktik hand hygiene merupakan suatu prosedur tindakan membersihkan tangan dengan menggunakan sabun atau antiseptic dibawah air mengalir atau dengan menggunakan handrub yang bertujuan untuk menghilangkan kotoran dari kulit secara mekanis dan mengurangi jumlah mikroorganisme sementara Darmadi, (2008).

Pendidikan diartikan sebagai proses penambahan sikap dan tatalaku seseorang atau kelompok orang dalam upaya mendewa-dewakan manusia, melalui upaya pengajaran dan pelatihan. Pendidikan berpengaruh pada cara berfikir tindakan dan pengambilan keputusan seseorang dalam melakukan suatu perbuatan semakin tinggi pendidikan dan pengambilan keputusan seseorang dalam melakukan suatu perbuatan semakin tinggi pendidikan seseorang akan semakin baik pengetahuan pentang kepatuhan. Pendidikan dapat menambah wawasan atau pengetahuan seseorang. Seseorang yang berpendidikan lebih tinggi akan mempunyai pengetahuan yang luas dibandingkan dengan seseorang yang berpendidikan ditingkat yang lebih rendah. Begitu pula dengan pengetahuan tentang pentingnya hand hygiene, seseorang yang berpengetahuan tinggi akan cenderung untuk melakukan pengendalian danlebih memperhatikan kebersihan tangan nya dibandingkan dengan seseorang yang berpengetahuan rendah.

Setelah dilakukan pendidikan kesehatan tentang hand hygiene, penunggu pasien mampu mengetahui bagaimna cara melakukan hand hygiene dengan baik dan benar. Semakin tinggi pendidikan seseorang maka akan semakin mudah pula penunggu pasien dalam menerima hal-hal yang baru misalnya melakukan 6 langkah hand hygiene. Dari pendidikan kesehatan yang diberikan tersebut ternyata mampu mengubah pandangan seseorang yang awalnya tidak mau melakukan setelah di lakukan pendidikan kesehatan pada penunggu pasien, mereka menjadi mampu melakukan hand hygiene dengan baik dan benar. 


\section{KESIMPULAN}

Setelah peneliti menganalisa data dan melihat hasil analisa maka peneliti dapat mengambil kesimpulan sebagai berikut:

1) Hampir seluruh penunggu pasien rawat inap di Puskesmas Karangbinangun Lamongan tidak melakukan hand hygiene dengan baik dan benar sebelum dilakukan pendidikan kesehatan

2) Hampir seluruh penunggu pasien rawat inap di Puskesmas Karangbinangun Lamongan melakukan hand hygiene dengan baik dan benar

3) Setelah dilakukan pendidikan kesehatan terdapat pengaruh pendidikan kesehatan hand hygiene pada penunggu pasien rawat inap di Puskesmas Karangbinangun Lamongan

Dapat dilakukan oleh penelitian dengan memperhatikan hasil penelitian yang diperoleh. Maka saran yang dapat dipertimbangkan untuk perbaikan adalah sebagai berikut:

1. Akademik

Dari hasil penelitian memberi sumbangan bagi ilmu pengetahuan tentang pengaruh pendidikan kesehatan terhadap praktik hand hygiene serta sebagai sarana pembanding bagi ilmu pengetahuan dalam menambah informasi tentang pengaruh pendidikan kesehatan terhadap praktik hand hygiene.

2. Bagi Praktisi

a. Bagi Responden

Hasil penelitian ini dapat memberikan informasi atau gambaran pada penunggu pasien mengenai pentingnya hand hygiene.

b. Bagi Instansi Kesehatan

Dapat meningkatkan mutu pelayanan dalam memberikan pendidikan kesehatan terhadap pentingnya praktik hand hygiene pada penunggu pasien

c. Bagi Profesi Keperawatan

Diharapkan hasil penelitian ini dapat digunakan dalam mengembangkan rencana asuhan keperawatan khususnya dalam melakukan edukasi dalam hal pendidikan terhadap praktik hand hygiene.

\section{DAFTAR PUSTAKA}

Arfianti, D. R. (2010). Factor-Faktor yang Berhubungan Dengan Tingkat Kepatuhan Hand Hygiene. Universitas muhammadiyah Semarang.

Arianto, S, (2009). Prosedur Penelitian Suatu Pendekatan Praktik. Jakarta :Rinka Cipta. 
Arikunto, Suharsini. 2006. Prosedur Penelitian Suatu Praktik. Jakarta : PT Rineka Cipta

Atikah, Eni, (2012). Perilaku Hidup Bersih Dan Sehat. Jakarta: EGC

Budiman, (2011). Penelitian Kesehatan. Bandung: PT Refika Aditma.

Darmadi, (2008). Infeksi : Problematika dan Pengendaliannya, Jakarta : Salemba Medika. Nursalam, (2013). Metodelogi Penelitian Ilmu Keperawatan. Edisi 3. Jakarta : Salemba Medika.

Demkes RI. (2010). Pedoman Pelaksanaan Kewaspadaan Universal, Departemen Kesehatan Republic Indonesia, Jakarta.

Dinkes RI, (2010), Konsep Dasar Pendidikan Kesehatan Jakarta: EGC

Dinkes RI, (2014), Konsep Pembangunan Bangsa Yang Sehat.Jakarta:EGC

Effendy, Hendra, (2010), Tujuan Penyuluhan Kesehatan, Jakarta:EGC

Elis Emawati. (2014). Journal Kedokteran Brawijaya, Vol 28, Suplemen No, 1

Enggar. (2012). Instrument Penelitian Keperawatan: Konsep dan Aplikasi Kebutuhan Dasar Klien. Jakarta

Notoatmojo S,(2010). Metodelogi Penelitian Kesehatan. Jakarta : PT Rineka Cita

Sobur, Alex, (2013). Psikologi Umum dalam Lintasan Sejarah. Bandung :CV Pustaka Setia.

Sugiono, (2013). Statistika Untuk Penelitian, Alfabeta,Bandung.

Susilo,(2011), Kegiatan Pendidikan Kesehatan. Bandung : Alfa Beta.

Wasiss, (2013). Pedoman Riset Praktis Untuk Profesi Perawat, Jakarta: Kedokteran EGC.

Metodelogi Penelitian Ilmu Keperawatan. Edisi 3. Jakarta : Salemba Medika.

Rahmad, Susilo, April 2011. Pendidikan kesehatan keperawatan.:Yogyakarta : Nuha Medika 
Notoatmojo S,(2012). Pengantar perilaku pendidikan kesehatan. Jakarta : PT Rineka Cipta

Effendy, Hendra, (2010), Tujuan Penyuluhan Kesehatan, Jakarta:EGC

Notoatmojo S,(2010). Metodelogi penelitian kesehatan. Jakarta : PT Rineka Cita 